\title{
Sternal diastasis; computerized tomography findings
}

\author{
Canan ALTAY ${ }^{1}$ \\ IşıI BAŞARA AKIN ${ }^{1}$ \\ PInar BALCI ${ }^{1}$
}

${ }^{1}$ Dokuz Eylül Üniversitesi Tıp Fakültesi, Radyoloji Anabilim Dalı, Izmir, Türkiye

${ }^{1}$ Department of Radiology, Faculty of Medicine, Dokuz Eylul University, Izmir, Turkey
To the Editor,

An 83-year-old male referred due to a sternal diastasis at the line of the sternotomy, which was incidentally observed on a thorax computerized tomography (CT) (Figure 1A). He underwent coronary artery bypass grafting surgery six years ago and had no complaint. The intraoperative course of the coronary artery bypass surgery was uncomplicated and the repair of the sternum was made properly at another hospital. The sagittal reformatted image and a three dimensional (3-D) CT scan revealed diastasis at the sternum and low degree herniation of the right ventricle to the subcutaneous fat tissue (Figure 1B,2).

On the palpation, there was sternal instability and pulsatile soft tissue mass in the line of diastasis. The patient was scheduled for surgical revision of the sternum. The sternum is a bone that extends horizontal through the middle of the anterior thoracic cavity (1). Sternal diastasis may be developing in elderly ages due to chest wall hyperexpansion (2). Physicians should be kept mind the sternal diastasis in the differential diagnosis of the pulsatile mass at the level of sternotomy line.

\section{Yazışma Adresi (Address for Correspondence)}

\section{Dr. Canan ALTAY}

Dokuz Eylül Üniversitesi Tıp Fakültesi, Radyoloji Anabilim Dalı, IZMiR - TÜRKIYE

e-mail: cananaltay@yahoo.com 


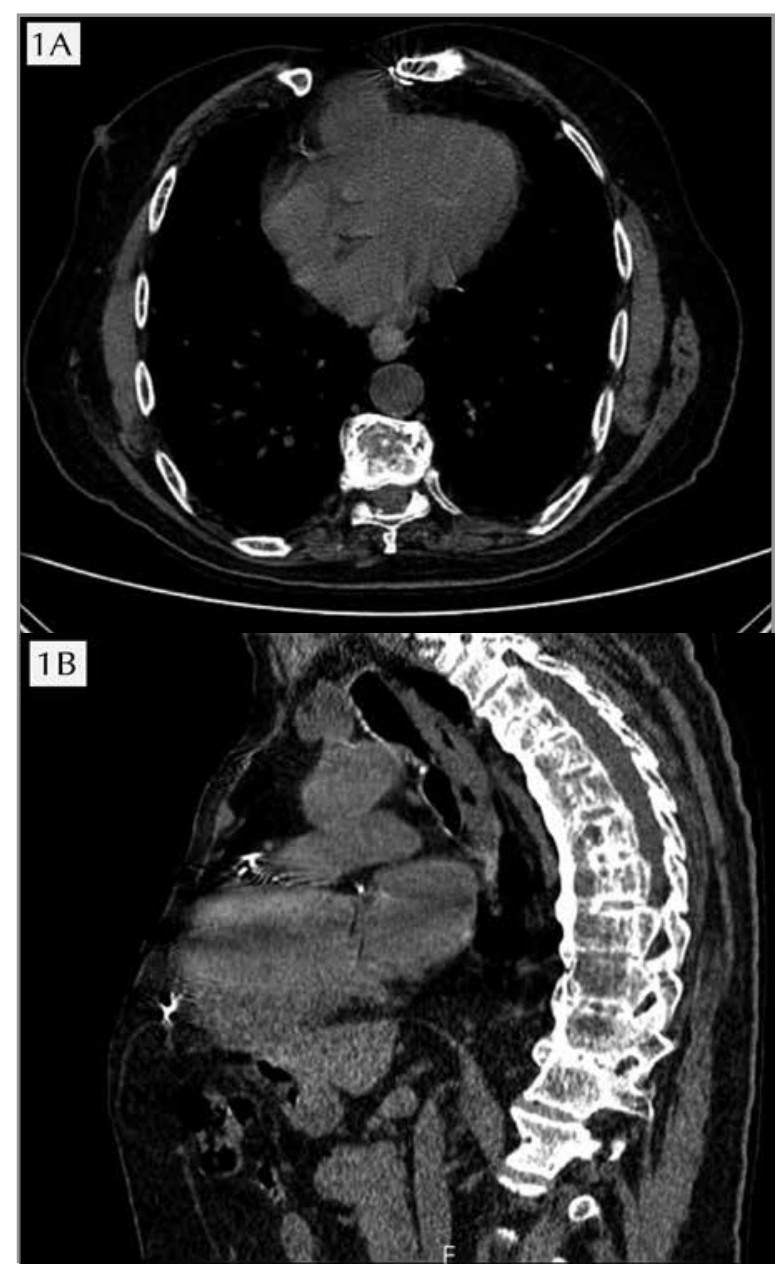

Figure 1. Axial thorax CT (A) and sagittal reformatted image (B) show sternum diastasis and the herniation of the right ventricle.

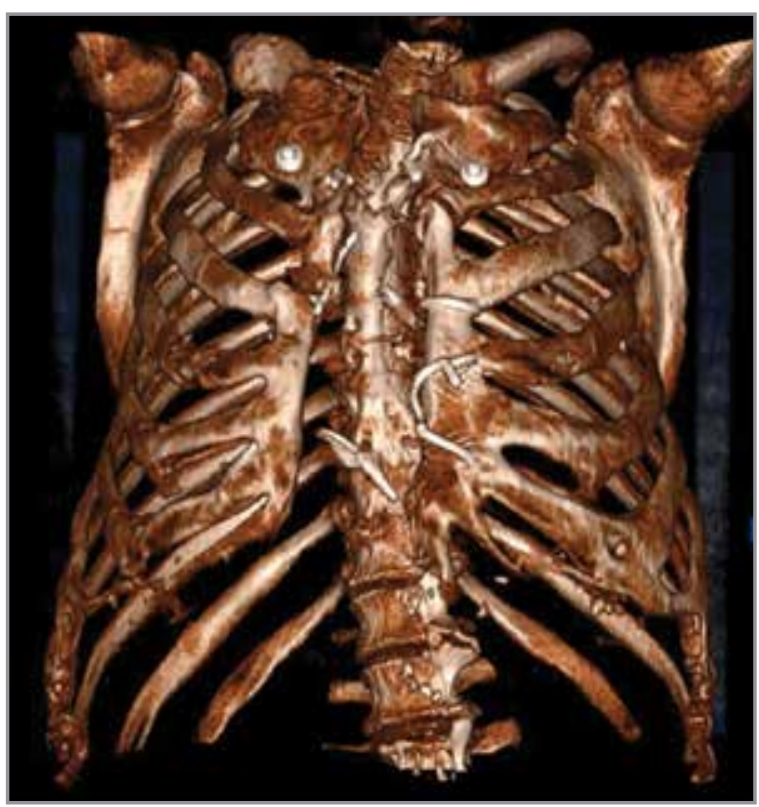

Figure 2. The volume rendering reformatted three dimensional (3-D) CT scan was verified sternal diastasis.

\section{REFERENCES}

1. Bayaroğulları $H$, Yengil E, Davran R, Ağlagül E, Karazincir $S$, BalCı A. Evaluation of the postnatal development of the sternum and sternal variations using multidetector CT. Diagn Interv Radiol 2014;20:82-9.

2. Santarpino G, Pfeiffer S, Concistré G, Fischlein T. Sternal wound dehiscence from intense coughing in a cardiac surgery patient: could it be prevented? G Chir 2013:34:112-1. 